\title{
Adaptation to High-Risk Childbearing: A Preliminary Situation-Specific Theory*
}

\begin{abstract}
The topic: Epistemology
Contribution to the discipline: Development of the theory that we present in this paper was guided by the Roy Adaptation Model of Nursing, which is one of the most widely used nursing conceptual models for research, education, and practice. The theory is based on data from a pilot study of mothers' and fathers' adaptation to high-risk childbearing, a population whose experiences have not yet been studied extensively. We regard the theory as preliminary, due to the small number of study participants, a number that is acceptable for a pilot study. We also regard the theory as situation-specific due to its focus on a specific population (expectant and new parents) and a specific health condition (childbearing). The theory adds to the continuing growing amount of theoretical literature associated with the Roy Adaptation Model and to the growing number of situation-specific theories. Future research with larger numbers of participants may provide data that will support or call for revisions of this preliminary theory and suggest ways in which the theory could be used to guide nursing practice with mothers and fathers who are experiencing high risk childbearing.
\end{abstract}

\section{ABSTRACT}

The purpose of this paper is to present a discussion of a preliminary situation-specific theory of adaptation to high-risk childbearing for expectant and new mothers and fathers. Roy's Adaptation Model guided the design and conduct of the pilot study of correlates of maternal and paternal functional status from which the theory was derived. The conceptual-theoretical-empirical structure for the study is displayed in a diagram. The concepts of the theory-functional status, physical symptoms, physical energy, psychological symptoms, and relationship quality--are identified and defined, and their linkages are identified. Implications for testing and potential use of the theory in nursing practice are discussed.

\section{KEYWORDS (SOURCE: DECS)}

Functional status; mothers; fathers; childbearing; reproductive behavior; Roy Adaptation Model; situation-specific theory.

\section{DOI: 10.5295/aqui.2018.18.4.3}

To reference this article / Para citar este artículo / Para citar este artigo

Fawcett J, Tulman L. Adaptation to High-Risk Childbearing: A Preliminary Situation-Specific Theory. Aquichan 2018; 18(4): 407-414. D0I: 10.5295/aqui.2018.18.4.3

$1 \bowtie$ orchid.org/0000-0002-1091-8873. Department of Nursing, University of Massachusetts, United States of America. jacqueline.fawcett@umb.edu

2 orcid.org/0000-0002-1579-0602. School of Nursing, University of Pennsylvania, United States of America. tulman@nursing.upenn.edu

* This paper is adapted from Fawcett J, Tulman L, Lowry L. Correlates of maternal and paternal functional status during high risk pregnancy and the postpartum: A pilot study. Roy Adaptation Association Review 2012, Spring; 15(2): 4-6. With permission of C. Roy. We are grateful to Dr. Lois Lowry (deceased) for her substantial contributions to the study that is the source of data for this paper.

\section{Recibiddo: 16/08/2018 \\ Enviado a pares: 14/09/2018 \\ Aceptado por pares: 10/10/2018 \\ Aprobado: 26/10/2018}




\section{Adaptación a la maternidad de alto riesgo: una teoría preliminar específica de la situación}

\section{RESUMEN}

El propósito de este artículo es presentar una discusión sobre una teoría preliminar específica, de la situación de la adaptación a la maternidad de alto riesgo, para las futuras madres y los nuevos padres. El modelo de adaptación de Roy sirvió de guía para el diseño y la realización del estudio piloto de correlatos del estado funcional materno y paterno del cual se derivó la teoría. La estructura conceptualteórico-empírica para el estudio se muestra en un diagrama. Se identifican y definen los conceptos de la teoría: estado funcional, síntomas físicos, energía física, síntomas psicológicos y calidad de la relación, y se identifican sus vínculos. Se discuten las implicaciones para las pruebas y el uso potencial de la teoría en la práctica de enfermería.

PALABRAS CLAVE (FUENTE: DeCS)

Estado funcional; madres; padres; parto; conducta reproductiva; Modelo de Adaptación de Calista Roy; teoría específica de la situación. 


\section{Adaptação à maternidade de alto risco: uma teoria preliminar específica da situação}

\section{RESUMO}

0 objetivo deste artigo é apresentar uma discussão de uma teoria preliminar específica da situação de adaptação à maternidade de alto risco para as futuras mães e os novos pais. 0 modelo de adaptação de Roy serviu como um guia para desenho e implementação do estudo piloto de correlatos do estado funcional materno e paterno do qual a teoria foi derivada. A estrutura conceitual-teórico-empírica para o estudo é mostrada em um diagrama. Os conceitos da teoria são identificados e definidos: estado funcional, sintomas físicos, energia física, sintomas psicológicos e qualidade da relação, e seus elos são identificados. As implicações para o teste e o uso potencial da teoria na prática de enfermagem são discutidas.

PALAVRAS-CHAVE (FONTE: DECS)

Estado funcional; mães; pai; parto; comportamento reprodutivo; Modelo de Adaptação de Roy; teoria em situação-específica. 
The purpose of this paper is to present a preliminary situation-specific theory that is based on the findings of a pilot study of correlates of maternal and paternal functional status during high-risk pregnancy and the postpartum (1), and to discuss how the theory could be tested and used in nursing practice. The pilot study and derivation of the theory were guided by Roy's Adaptation Model (RAM) (2).

A pilot study typically includes a relatively small number of participants and is conducted to determine whether a study with a larger number of participants would be feasible. Determination of feasibility includes the appropriateness of the research design, the adequacy of the procedures used to recruit and retain participants and to collect and analyze the data, the appropriateness of the empirical indicators (research instruments), and effect sizes $(3,4)$. Effect size refers to the magnitude of the association between empirical indicators for concepts, rather than statistical significance (5).

A situation-specific theory is defined as a set of concepts and statements about the concepts that address a specific population and a specific health condition (6). The statements about the concepts include their theoretical and operational definitions, and the links between the concepts. Definitions are the non-relational propositions of a theory, whereas statements of linkages are the relational propositions (3). Our preliminary situation-specific theory focuses on a population of expectant and new mothers and fathers experiencing high-risk childbearing.

The pilot study was the next step in a program of research addressing functional status during low-risk childbearing, which began 30 years ago with women from Mid-Atlantic states (7-9) The pilot study was approved by university and hospital institutional review boards and all participants gave written or oral informed consent. Each study participant was compensated $\$ 10$ for time spent on data collection. The participants, who resided in either a New England or a Southern state of the United States of America, were recruited from hospital clinics and a private physician's office. The typical study participant was 31 years of age; white, non-Hispanic; had at least a high school education; and was employed outside the home or was on maternity or paternity leave. Data were collected in person or by telephone. Descriptive statistics (means, standard deviations, ranges) indicated that maternal functional status was relatively high during pregnancy, whereas paternal functional status was moderate at that time.
Both maternal and paternal functional status was moderate during the postpartum.

\section{The Preliminary Situation-Specific Theory: Adaptation to High-Risk Childbearing}

The conceptual-theoretical-empirical structure for the pilot study is depicted in the Figure. As can be seen in the Figure, the RAM adaptive system was represented by expectant and new mothers and fathers; the samples from the pilot study were the empirical indicators. The focal stimulus was represented by high-risk pregnancy, as documented by a healthcare provider. Contextual stimuli were represented by demographic variables, recorded on the Background Data Sheet; these data were used to describe the characteristics of the samples.

The five concepts of the situation-specific theory of adaptation to high-risk childbearing were linked to the RAM adaptive modes. Functional status, measured by Inventories of Functional Status (10-12), represented the RAM role function mode. Physical symptoms, measured by the Symptoms Checklist (13), and physical energy, measured by the Physical Energy Scale (8), represented the RAM physiological mode. Psychological symptoms, measured by the Symptoms Checklist (13), represented the RAM self-concept; relationship quality, measured by the Relationship Change Scale (14), represented the RAM interdependence mode. (See the Figure). The theoretical definition for each concept and the way in which each concept was measured are given in Table 1.

The relational propositions for the situation-specific theory are based on the RAM proposition that responses in one adaptive mode are associated with responses in other adaptive modes (2). For the purposes of development of the situation-specific theory of adaptation to high-risk childbearing, the relations of the physiological, self-concept, and interdependence modes to the role function mode are relevant. The relational propositions of the theory, which are listed below, were determined by an examination of the magnitude of the correlations of the empirical indicators for the theory concepts representing the modes of adaptation. The correlations seen in Table 2 are interpreted as effect sizes; statistical significance was not relevant due to the small sample sizes (5). Correlations below 0.10 are too small to be considered as meaningful relations and, therefore, are not included as relational propositions for the theory. 
Figure 1. Conceptual-Theoretical-Empirical Structure for a Pilot Study of Correlates of Maternal and Paternal Functional Status during High-Risk Pregnancy and the Post-Partum.

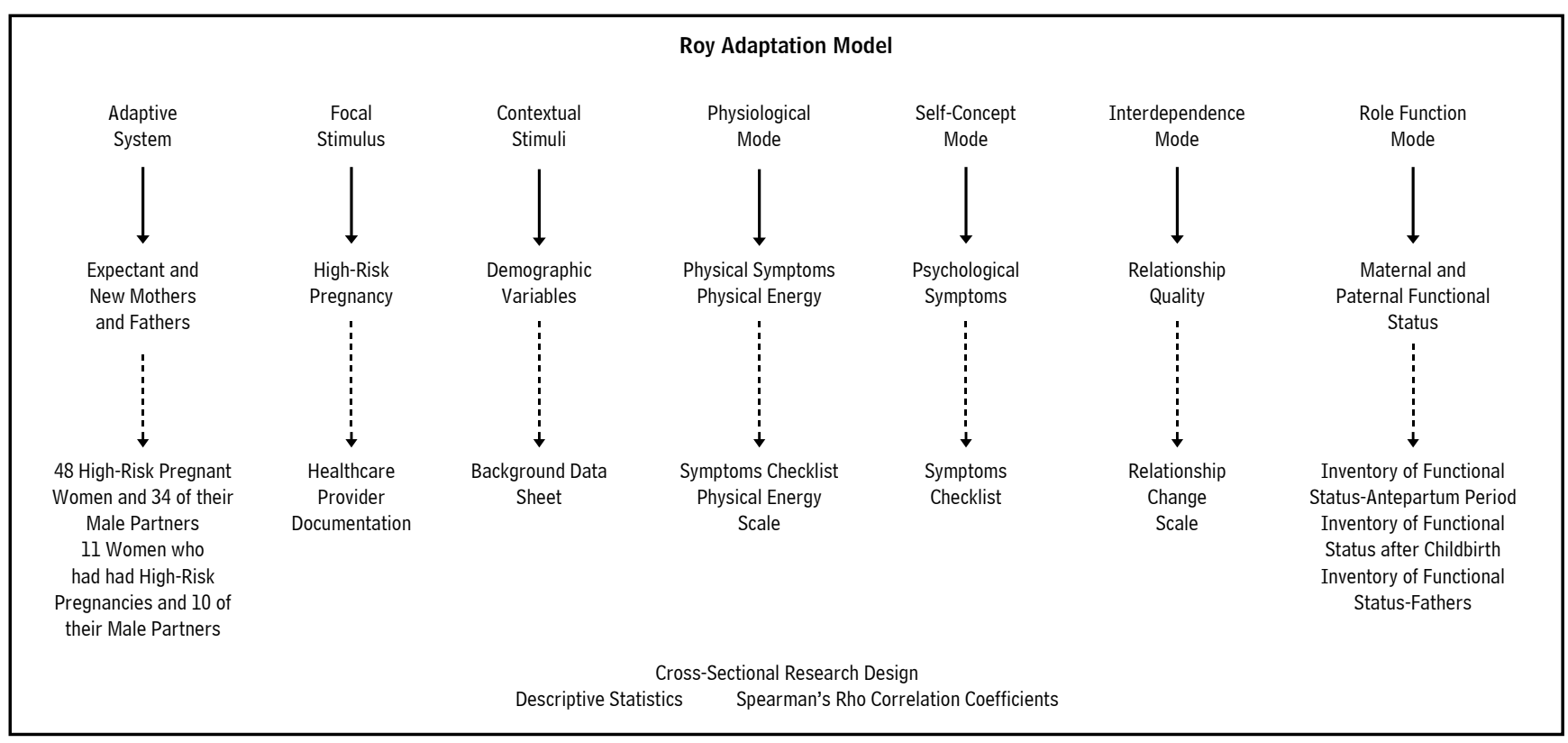

Source: Own elaboration.

Table 1. Definitions of the Concepts of the Theory of Adaptation to High-Risk Pregnancy

\begin{tabular}{|c|c|}
\hline Concept & $\begin{array}{l}\text { Theoretical Definitions } \\
\text { Empirical Indicators }\end{array}$ \\
\hline Functional Status & $\begin{array}{l}\text { Continued performance of an individual's usual household, social and community, family, personal care, occupational, and educational } \\
\text { activities during pregnancy and the postpartum, and assumption of infant care responsibilities during the postpartum } \\
\text { Inventory of Functional Status-Antepartum Period (Tulman et al., 1991) } \\
\text { Inventory of Functional Status after Childbirth (Fawcett, Tulman, \& Myers, 1988) } \\
\text { Inventory of Functional Status-Fathers (Tulman, Fawcett, \& Weiss, 1993) }\end{array}$ \\
\hline Physical Symptoms & $\begin{array}{l}\text { Twenty common physical complaints and/or discomforts experienced during pregnancy or the postpartum ( indigestion, nausea and/or } \\
\text { vomiting, increase or decrease in appetite, food cravings, constipation, diarrhea, increased urination, hemorrhoids, backache, toothache, } \\
\text { difficult breathing, sensitivity to odors, skin irritations, feel warmer than usual, feel bloated, more or less active than usual, feel clumsy } \\
\text { or awkward, feel tired or sleep often) } \\
\text { Symptoms Checklist (Fawcett \& York, 1986) }\end{array}$ \\
\hline Physical Energy & $\begin{array}{l}\text { Level of energy felt during pregnancy or the postpartum compared to pre-pregnancy level of energy } \\
\text { Physical Energy Scale (Tulman \& Fawcett, 2003) }\end{array}$ \\
\hline $\begin{array}{l}\text { Psychological } \\
\text { Symptoms }\end{array}$ & $\begin{array}{l}\text { Three common emotional feelings during pregnancy or the postpartum (anxiety, depression, feel better than usual) } \\
\text { Symptoms Checklist (Fawcett \& York, 1986) }\end{array}$ \\
\hline $\begin{array}{l}\text { Relationship } \\
\text { Quality }\end{array}$ & $\begin{array}{l}\text { The individual's perception of changes in the relationship with his or her partner with regard to satisfaction, communication, trust, } \\
\text { intimacy, sensitivity, openness, and understanding, compared to prior to the current pregnancy } \\
\text { Relationship Change Scale (Guerney, 1977). }\end{array}$ \\
\hline
\end{tabular}


Table 2. Effect Sizes (Spearman's Rho Correlation Coefficients) for Correlates of Maternal and Paternal Functional Status during Pregnancy and the Postpartum

\begin{tabular}{|c|c|c|c|c|}
\hline $\begin{array}{c}\text { Inventories of Maternal and Paternal } \\
\text { Functional Status }\end{array}$ & $\begin{array}{c}\text { Symptoms } \\
\text { Checklist-Physical } \\
\text { Symptoms }\end{array}$ & $\begin{array}{l}\text { Physical Energy } \\
\text { Scale }\end{array}$ & $\begin{array}{l}\text { Symptoms } \\
\text { Checklist- } \\
\text { Psychological } \\
\text { Symptoms }\end{array}$ & $\begin{array}{l}\text { Relationship } \\
\text { Change Scale }\end{array}$ \\
\hline $\begin{array}{l}\text { Maternal Functional Status: Inventory of } \\
\text { Functional Status-Antepartum Period }\end{array}$ & $-0.39 * \star$ & $0.39 * *$ & 0.04 & -0.02 \\
\hline $\begin{array}{l}\text { Paternal Functional Status: Inventory of } \\
\text { Functional Status-Fathers (Pregnancy) }\end{array}$ & 0.08 & -0.03 & 0.01 & $-0.20 *$ \\
\hline $\begin{array}{l}\text { Maternal Functional Status: Inventory of } \\
\text { Functional Status after Childbirth }\end{array}$ & $-0.22^{\star}$ & $0.23 *$ & $-0.37 * \star$ & $-0.43 * \star$ \\
\hline $\begin{array}{l}\text { Paternal Functional Status: Inventory of } \\
\text { Functional Status-Fathers (Postpartum) }\end{array}$ & $0.14 *$ & $-.29 * \star$ & 0.05 & 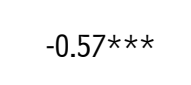 \\
\hline
\end{tabular}

$\star$ Small effect sizes $(r h o=.10)$ are considered relations of low magnitude; $* \star$ Medium effect sizes $($ rho $=.30)$ are considered relations of moderate magnitude; $\star \star \star$ Large effect sizes $($ rho $=.50)$ are considered relations of large magnitude.

Source: Own elaboration

During pregnancy, for expectant mothers:

- There is a negative relation of moderate magnitude between physical symptoms and maternal functional status; so, the greater the number of physical symptoms, the lower the maternal functional status.

- There is a positive relation of moderate magnitude between physical energy and maternal functional status; so, the greater the level of physical energy, the higher the maternal functional status

During pregnancy, for expectant fathers:

- There is a negative relation of low magnitude between relationship quality and paternal functional status; so, the less the change in relationship quality, the greater the paternal functional status

During the postpartum, for new mothers:

- There is a negative relation of low magnitude between physical symptoms and maternal functional status; so, the greater the number of physical symptoms, the lower the maternal functional status.
- There is a positive relation of low magnitude between physical energy and maternal functional status; so, the greater the level of physical energy, the higher the maternal functional status

- There is a negative relation between psychological symptoms and maternal functional status; so, the greater the number of psychological symptoms, the lower the maternal functional status.

- There is a negative relation of moderate magnitude between relationship quality and maternal functional status; so, the less the change in relationship quality, the greater the maternal functional status.

During the postpartum, for new fathers:

- There is a positive relation of low magnitude between physical symptoms and paternal functional status; so, the greater the number of physical symptoms, the higher the paternal functional status

- There is a negative relation approaching moderate magnitude between physical energy and paternal functional status; so, the greater the physical energy, the lower the paternal functional status 
- There is a negative relation of large magnitude between relationship quality and paternal functional status; so, the less the change in relationship quality, the greater the paternal functional status.

\section{Discussion}

As can be seen in Table 2, the correlations on which the relational propositions are based revealed that correlates of maternal functional status differ from correlates of paternal function status, These correlations also revealed that physical symptoms and physical energy during pregnancy have relations with maternal functional status of stronger magnitude than did these concepts during the postpartum; that is, effect sizes were larger during pregnancy than during the postpartum. In addition, the correlations revealed that relationship quality had the greatest influence on both maternal and paternal functional status postpartum than any other concept; that is, the largest effect sizes were for relationship quality for both parents during the postpartum.

\section{Implications for Nursing Research and Nursing Practice}

The situation-specific theory of adaptation to high-risk pregnancy is at a preliminary stage of development. Future research should focus on determining the empirical adequacy of the theory by testing each of the relational propositions to determine whether the effect sizes are stable with larger samples. Ideally, a longitudinal study should be conducted to follow expectant parents from early in pregnancy through at least six months postpartum.

Although it is tempting to recommend how the theory could be used in practice at this time, it is important to wait until research findings indicate whether the theory is empirically adequate. However, a test of the theory could be conducted in the "real world" of clinical nursing practice, rather than in a "formal" research project. The benefit of this approach would be that a nurse researcher from a university could form a partnership with one or more nurses who are in the "real world" of practice to test the theory propositions, as well as to determine the feasibility of implementing the theory in practice.

\section{References}

1. Fawcett J, Tulman L, Lowry L. Correlates of maternal and paternal functional status during high risk pregnancy and the postpartum: a pilot study. RAA Rev. 2012; 15(2): 4-6.

2. Roy C. The Roy Adaptation Model. $3^{\text {rd }}$ ed., Upper Saddle River (NJ): Pearson, 2009

3. Fawcett J, Garity J. Evaluating research for evidence-based nursing practice. Philadelphia (PA): FA Davis Company, Publishers, 2009.

4. Prescott PA, Soeken K. The potential uses of pilot work. Nurs Res. 1989; 38:60-62.

5. Cohen J. A power primer. Psych Bull. 1992; 112:155-9.

6. Meleis AI. Theoretical nursing: development and progress. 5th ed., Philadelphia (PA): Wolters Kluwer Health/Lippincott Williams \& Wilkins. 2012

7. Tulman L, Fawcett J. Return of functional ability after childbirth. Nurs Res, 1988: 37: 77-81.

8. Tulman L, Fawcett J. Women's health during and after pregnancy: a theory-guided study of adaptation to change. New York (NY): Springer Publishing Company, 2003.

9. Tulman L, Fawcett J, Groblewski L, Silverman L. (1990). Changes in functional status after childbirth. Nurs Resl 1990; 39:70-5.

10. Tulman L, Higgins K, Fawcett J, Nunno C, Vansickel C, Haas MB, et al. The inventory of functional status-antepartum period: development and testing. J Nurs Midwif. 1991; 36:117-23. 
11. Tulman L. Fawcett J. Weiss M. The inventory of functional status-fathers: development and psychometric testing. J Nurs Midwif. 1993; 38:276-82.

12. Fawcett J. Tulman L, Myers ST. (1988). Development of the inventory of functional status after childbirth. J Nurs Midwif. 1988; 33:252-60.

13. Fawcett J, York R. Spouses' physical and psychological symptoms during pregnancy and the postpartum. Nurs Res.1986; 35:144-8.

14. Guerney BG. Relationship enhancement. San Francisco (CA): Jossey-Bass, 1977. 